\title{
Language and Law in Multiethnic Societies: The Case of Transylvania
}

\author{
Emőd Veress ${ }^{1,2}$ (D)
}

Published online: 17 July 2020

(c) The Author(s) 2020

\begin{abstract}
Transylvania is a multiethnic society that was part of the Hungarian legal space for centuries. Still, after the WWI, this territory became part of Romania, alongside with a significant number of Hungarian-speaking minority population. What happened with Hungarian as a legal language after the annexation of Transylvania to Romania? The article deals with the history and current status of Hungarian legal language in Romania, emphasizing the frequent contradictions between legal texts and realities, the importance of political context, and fluctuations in the minority rights. The focus is on two problems: the language of legal education and the language of the court proceedings. There are arguments brought to prove the conditionality between these two at the intersection of history of legal education and minority rights.
\end{abstract}

Keywords Transylvania $\cdot$ Language of legal education · Language of court proceedings · Bolyai University · Sapientia University

\section{Context}

At the end of the year 1918, de facto, and in 1920, de jure, according to the Trianon Peace Treaty, Transylvania, a historical region of East-Central Europe, became part of Romania. According to the census conducted in 1910, 53.8\% of the Transylvanian population was Romanian, and 31.6\% Hungarian. Transylvania, as a region, had a central role in Hungarian history and culture. Therefore the annexation of this territory was perceived as a significant loss by Hungarians. Meanwhile, the Romanians saw as a unification of the Romanian-speaking people and great political achievement. As an effect of the Trianon Peace Treaty concluded precisely 100 years ago,

Emőd Veress

emod.veress@icloud.com

1 Department of Private Law, Ferenc Mádl Institute of Comparative Law, Budapest, Hungary

2 Department of Law, Sapientia Hungarian University of Transylvania, Cluj-Napoca, Romania 
Hungary lost one-third of its ethnic Hungarian population to other states where Hungarians formed a significant national minority. This loss is why the Trianon Peace Treaty is still seen in the historical literature as controversial, with just a partial ethnic justification, and its over-sanctioning nature is regularly reflected. The territorial profit also defines Romanian political thinking: it is perceived as a gain that must be protected, and the mere existence of national minorities permanently threatens this territorial gain. Therefore a two-faceted politics was born, targeting in one direction: on the one hand, the outward appearance of a minority-friendly policy was created, as it contributed preserving territorial gains; on the other hand, the minority was the internal enemy, whose emigration and assimilation is desirable, for the same purpose. This approach that the territorial gains can be loosed was confirmed by the Second Vienna Award (1940), ${ }^{1}$ which returned part of Transylvania, the so-called Northern Transylvania, to Hungary, while South Transylvania remained with Romania. The settlement came from Hitler and Mussolini, so it was inherently poisonous, but most likely, it would have been the closest to fairness. After the entry of the Soviet army (autumn 1944) and after the Soviet military administration, Romania received back the whole territory again (1945) and is still part of Romania. Nevertheless, the Romanian political culture also inherited the dual-faceted attitude to the national minorities to the Soviet-type dictatorship, and during this period, the communist leadership completed the Romanian nationalist program. In the present day, after several waves of mass-emigration, $17.8 \%$ of the population in Transylvania still belongs to the Hungarian minority. ${ }^{2}$

Before 1920, the language of legal education (at the university in the "capital city" of Transylvania, Cluj/Kolozsvár ${ }^{3}$ ) and of the courts was Hungarian. This article focuses on what happened after WWI in Transylvania in terms of the language of legal education and judicial proceedings.

\section{Language of Legal Education in the Twentieth Century Transylvania}

The university is one of the most essential, central institutions of any human society. In 1872, in the eastern part of the Austro-Hungarian Empire, in Cluj/Kolozsvár, Transylvania's capital, one of the founding faculties of the new Franz Joseph University, was the Faculty of Law and Political Sciences, where the language of legal education was Hungarian. The tradition of legal education goes back to 1581 when a short-lived university was founded, but the much more permanent legal education started in 1733 in the protestant college, and in 1774, at the Catholic Legal Academia founded by empress Maria Theresa. 1872 marked the foundation of the first modern university in Transylvania, with a renowned staff of professors as well.

\footnotetext{
${ }^{1}$ For details on the Second Vienna Award, see [1: 23-38].

2 The German minority of Transylvania emigrated even more massively.

${ }^{3}$ Cluj (or Cluj-Napoca) is the present-day Romanian name, Kolozsvár is the traditional Hungarian name of the city.
} 
After WWI, the multiethnic Transylvania, and its "capital," Cluj/Kolozsvár was annexed to Romania. Making use of the infrastructure of the Franz Joseph University (which had moved to Budapest for a short period and then was relocated permanently to Szeged, Hungary) in 1919 the King Ferdinand I University was founded in Cluj/Kolozsvár; the language of legal education became exclusively Romanian.

Based on the facts presented above, a simple rule can be set up: the language of legal education depends on whoever exercises sovereignty over Transylvania. The same rule prevailed between 1940 and 1944 as well: when Northern Transylvania, and with that, Cluj/Kolozsvár was returned to Hungary under the Second Vienna Award, the university that returned from Szeged to Cluj/Kolozsvár provided legal education only in Hungarian, while the Romanian university moved to Sibiu/Nagyszeben, to Southern Transylvania which remained under Romanian sovereignty.

According to the 1942 analysis of Gyula László (1910-1998), professor of archaeology, the Romanians after the First World War immediately realized that Cluj/Kolozsvár required something different from a regular university: "Cluj/ Kolozsvár was an intellectual border fortress and bastion. The Romanian university in Cluj/Kolozsvár set as its goal the research of the Romanian life, especially the research of Transylvania's Romanian nature, and the permanent international publication of the results. There is no doubt that parts of this work had significant results from the international point of view as well (e.g., the pioneering work of the Romanian language atlas). From their point of view, they did a perfect job, and the state did not spare any money or other types of support to serve the great cause" [2: 464-465]. Gyula László criticized the situation of the Franz Joseph University, of the institution which has moved back to Cluj/Kolozsvár in 1940 under the Second Vienna Award in order to create a comprehensive development program. "If contrasted with the Franz Joseph University, the first thing to be noted is that it did not differ in any way from the structure based on humanities of the other universities in Hungary. It could be freely moved to any Hungarian territory, as its organization does not express in any way the fact that it protects a fortress and builds a bastion" [2: 465].

The Second Vienna Award proved to be a temporary settlement, and the implementation of Gyula László's program (for example, the founding of the Department of the History of Transylvania and the Department of the History of Hungarian Settlements, the launch of coordinated research programs) did not take place.

This short analysis shows that both the Romanians and the Hungarians saw the university as the main instrument in attaining their own national goals in Transylvania. "Our own university" is was perceived not only as a question of language but that of control as well: the university is a framework where research programs can be directed and coordinated to serve national purposes. Thus, between 1872 and 1919, only the Hungarian, between 1919 and 1940, only the Romanian, while between 1940 and 1944, only the Hungarian was the language of university-level education in Cluj/Kolozsvár.

There is a surprising change to this fact in 1945: an exception under the historical rule. In 1944-1945 Transylvania was reunited under Romanian sovereignty. The Romanian university moved back from Sibiu/Nagyszeben to Cluj/Kolozsvár. 
However, in parallel, a university with Hungarian as the language of instruction was founded on June 1, 1945, receiving the name Bolyai in December to honor two Transylvanian mathematicians, father and son, Farkas Bolyai (1775-1856) and János Bolyai (1802-1860). The university also included the Faculty of Legal and Economic Sciences. The question arises: does this mean that one of the critical issues of the nationalist rivalry between Romanians and Hungarians in Transylvania was at least partially concluded on a positive note? Those who are familiar with the situation also know that the answer is, unfortunately, negative.

How did and how could the Bolyai University in Cluj/Kolozsvár be established in 1945? It was the result of circumstances and politics. However, it was not created by an organic political agreement, nor by the free will of the new, post-war government of the country that aimed to settle the situation of national minorities in a positive note. The existence of the Bolyai University is due to an exceptional, unusual situation, and its path - as we shall see-inevitably turned in the direction of dissolution, its virtual termination in 1959 (trough the merger with the Romanian university and cessation of the Hungarian language legal education, marking the return of legal education to the linguistic monism prevailing before 1945).

The first reason for this detour from the historical routine was that the Hungarian university that was moved back from Szeged to Cluj/Kolozsvár in 1940 was not closed. On September 14, 1944, Sándor Vita, a moderate politician, formulated a short letter signed by several leading Hungarian politicians and intellectuals in support of the Hungarian university. The letter is addressed to Dezső Miskolczy, professor of medicine, rector of the university: "Being aware of our responsibility towards Hungarian-language science and culture in Transylvania, we turn to your Magnificence to consider the importance of the continuance of the century-long cultural life of the Transylvanian Hungarians, and convince the Council of the Hungarian University of Transylvania not to let themselves influenced by anything and anyone-even while trying to escape the threat of war and within the limits of their possibilities - in their determination to keep the five faculties and the departments of the university in Cluj/Kolozsvár" [2: 488]. Thus, despite the evacuation order, the university stayed in Cluj/Kolozsvár. In a period where the territorial status of (Northern) Transylvania was not officially decided yet, Romanian politics was under pressure, as they had to collaborate with the Soviets who, on their behalf, were skilfully manipulating the Transylvanian issue in order to achieve their goals. In such a context, the full removal of the university was not an acceptable step. In this historical ambiance, we should interpret the decree of King Michael I issued on May 28, 1945, regarding the establishment of a new university with Hungarian as the language of instruction, on June 1, 1945. This was a covert, but a politically defensible step to formally terminate the activity of the Franz Joseph University: the establishment of a new institution.

Therefore, the approach that links the foundation of Bolyai University with a real decrease of Romanian nationalism is wrong. Such swift and fast ideological enlightenment did not happen and was not possible. Short-term political goals were much more significant than the long-term settling of the national minority issue.

The second reason, however, is the left-wing idealism of some Transylvanian Hungarians, which I consider a serious factor. In essence, the Hungarian leftists 
believed that the existence of this university as justified, and its creation after WWII was natural and self-evident. They also began to act in this spirit. This action is also one of the factors of the creation of the university. The closing of the university in 1959 was a massive disappointment to Hungarian communists and other the leftists who supported the system. The idealistic left-wing activists were mere tools in the hands of the dictatorship, and this idealism caused them even some years in prison.

As the foundation of the Bolyai University was the result of circumstances, it was not a desired and wanted institution, but a tolerated one. It was established with extraordinary difficulties (the returning Romanian university took the buildings, collections, student houses over). It could have even be predicted that its fate was sealed. The possibility of the 1959 merger was encoded into its establishment. Nevertheless, the independent Bolyai University functioned, more exactly was able to function for 14 years. ${ }^{4}$ Much research needs to be conducted to have a full and precise picture of the university's history: Romanian and even Russian archives could hold significant surprises. Researching the archives can provide information, for example, on how the founding of the Bolyai University was seen in Bucharest in 1945, on the role of legal professionals in the dictatorship.

It is not a goal to paint an idealized picture of this university with a symbolic weight and value to the Hungarians of Transylvania. From 1945 onwards, Romania witnessed the unfolding of a totalitarian dictatorship that replaced the diversity of ideas with the forced domination of only one idea: the very much mundane distorted images of utopian communism, that is, Leninism and Stalinism. In its first years, a typical university, from 1947 it was transformed into a so-called Marxist university. The highly respected and admired teachers from Hungary (such as László Buza, professor of public international law and György Bónis, professor of legal history) who used to work at the Franz Joseph University were sent back to Hungary against their will. Legal education had political goals: the old "cadres," especially judges and prosecutors, had to be replaced with lawyers educated in the spirit of the new Soviet-type system. Bourgeois judges and prosecutors were remnants of a bygone age and needed to be replaced because of their untrustworthiness. Lawyers educated in the new spirit were meant to implement socialist justice, sentence people to death, or conduct show trials. György Fekete (1911-2002), professor of civil law, for instance, starts his book on the general theory of civil law published in 1958 with the following text. "Soviet armed forces crushed German and Japanese fascist armies and thus made it possible for several European and Asian states to break the chains of imperialism forever" [4:2].

Ideology impregnated education. The condition of every professor's appointment was the loyalty to the system, and the professors were scrutinized continuously. Nevertheless, several waves of layoffs took place; some professors were even sent to jail. For example, even the committed communist János Demeter (1908-1988), professor of constitutional law, was in jail for political reasons between 1952 and 1955.

After the 1956 uprising and revolution in Hungary demanding the end of Soviet rule and as a consequence of its defeat, in Transylvania, the fragile and informal

\footnotetext{
${ }^{4}$ For a detailed history of the legal education at Bolyai University, see [3].
} 
political compromise between leftist Romanians and Hungarians failed, and one of the anticipated signs and proofs of this failure was the merger of the two universities in Cluj/Kolozsvár. The 1959 merger, decided by the communist party (by its official name in this period: Romanian Workers Party), ended the history of the Bolyai University. Szabédi László, one of the university professors who committed suicide, sent his final note to the county party committee secretary. ${ }^{5}$

The letter says the following: "With the occasion of the meeting regarding the merger of the two universities, I was convinced that I was surrounded by informant eyes and ears... The only goal of my life was the happiness of the working class (the working people), and communism is where our People's Republic is heading towards. Long live the bright future of the socialist world!'[5: 303-304].

A part of the professors at the law school of the Bolyai University was transferred to the merged university. However, no new Hungarian speaking teachers were employed at the Law Faculty. The transferred professors of the former Bolyai University continued to teach in the Romanian language. While in the case of other specialties, we can speak about the survival of the Bolyai University inside the newly merged entity, this is not the case of legal education, where continuity was disrupted. In fact, the merger was a return to the original rule that connected the language of legal instruction directly to the one exercising sovereignty. Hungarian language legal education, which by its nature had a prominent long-term anti-regime (anti-communist) potential, was closed. The Romanian political rulers perceived that the ideas of the 1956 Hungarian Anticommunist Revolution are widespread among Hungarians in Romania, and the Bolyai University with its intellectual base can be a core of anti-communist thinking. The fall of the Bolyai University meant the end of the central and representative Hungarian intellectual center in Transylvania.

The graduates of the Bolyai University have accomplished outstanding professional performances in a variety of legal fields. The lawyer graduates of the Bolyai University have formed until recently one of the most important intellectual groups of the Hungarians from Transylvania. Several university professors-including two outstanding professors of the Faculty of Law at the University of Bucharest, like civil law professor Ferenc (Francisc) Deák (1927-2001), judges, including judges of the Supreme Court, prosecutors, attorneys, administrative professionals graduated from the Bolyai University. A Hungarian judge of the Romanian Constitutional Court created after the collapse of the soviet type dictatorship was a former student of the Bolyai University (Gábor Kozsokár). Alumni from the Bolyai University were appointed as members of the Government or became deputies and senators in the Parliament of Romania.

Between 1945 and 1959, legal education at the Bolyai University was carried out exclusively in Hungarian; however, it trained legal professionals for the Romanian judicial system at an extremely high level. The explanation is simple: the thorough,

\footnotetext{
5 Several university professors protested the merger by committing suicide, such as the vice-rector Zoltán Csendes (1924-1959). His wife followed him a short period later. Unfortunately, the rector of the university who was forced to play an active role in the merger and the cessation of the legal education in Hungarian was Lajos Takács (1908-1982), professor of public international law.
} 
profound legal knowledge acquired in the mother tongue can constitute a solid base for professional skills also in a bilingual context. However, the professional knowledge acquired in Romanian only superficially and partially is more challenging to be deepened.

Thus, the merger of the Romanian Victor Babeș University and Bolyai University represents a fundamental breaking point in Transylvania's legal education and a return to the historical rule, because the merger marked the end of Hungarian legal education. Politics disrupted the continuity of Hungarian legal language and legal culture in Transylvania once again as in 1920. The results of this affected the entire Hungarian minority.

Firstly, the merger led directly to the gradual disappearance of the Hungarian legal language in Transylvania. Hungarian legal practitioners studying the law in Romanian started to use a mixed language with each other that includes Romanian legal terms - since the Hungarian legal terminology has withered. The legally recognized rights on the use of mother tongue faded, and even after the collapse of the Soviet-type dictatorship, the newly recognized minority rights to often remained on paper also because the group of legal professionals who could provide content to these rights was missing.

Secondly, the merger of the two universities made it possible to control and minimize the number of Hungarian speaking legal professionals with law degrees and high qualifications who had to learn in Romanian after 1959. These measures resulted in the fact that Hungarian speakers are massively underrepresented among magistrates, way under the Romanian/Hungarian population ratio. In the present, in the whole of Romania, some $1.2 \%$ of judges and prosecutors are Hungarians, while $6.5 \%$ of the total populations belong to this minority.

After the fall of the Soviet-type dictatorship, the Hungarian minority in one of its political goals, the reestablishing of the Bolyai University, was unsuccessful. As a result for this failure, historical Hungarian churches in Transylvania (the Calvinist Reformed Church, the Roman Catholic Church, the Unitarian Church, and the Evangelical Lutheran Church) founded the Sapientia Hungarian University of Transylvania, as a private university, to complement education in the areas where the Romanian state is not offering mother-tongue university education. ${ }^{6}$ Starting with 2010, this university established a bilingual, Romanian-Hungarian law school (Department of Law).

The present is an experimental one: it is possible remodeling the historical rule?

The experience of Hungarian legal education between 1945 and 1959 should be somehow utilized in the bilingual legal education at the Sapientia University. For instance, while teaching the general theory of the civil law in Romanian, it was found that the Hungarian first-year students have difficulties understanding and learning the Romanian curriculum. The "shock effect" caused by the abstract nature of the legal language and reasoning also affects the Romanian students. Therefore this is not surprising. The question is whether this understanding of Romanian legal

\footnotetext{
${ }^{6}$ Also, the establishment of the Sapientia University was motivated by the lower percentage of Hungarian university students in Romania than the percentage of Hungarian-speaking population.
} 
text by a Hungarian student can be improved by the mother tongue, in conditions where the lectures and exams take place in Romanian. This subject, like all other subjects, was taught in Hungarian at the Bolyai University. It was during the last moment of the Hungarian legal education at the Bolyai University, in 1958, when the last Hungarian textbook on the general theory of the Romanian civil law was published. György Fekete's book [4]—if we cast aside the mandatory ideological burden of that time-is a thorough and accurate work. However, the archival sources indicate that professor György Fekete was reprimanded because he did not emphasize the ideology enough. He only described civil law, while avoiding presenting the "class aspects" of civil law-which was expected and required by the dictatorship [3: 152-153].

After the abolition of the independent Bolyai University in 1959, no Hungarian language textbooks discussing the general theory of the Romanian civil law were published until 2016. As indicated above, the civil law subjects are taught in Romanian at the Sapientia University, and so is criminal law and procedural laws. However, in addition to a detailed, 400-page Romanian language textbook published in 2012 [6], in 2016, it was drawn up a first schematic Hungarian coursebook [7, the fourth edition 15]. This short textbook does not intend to replace learning the more detailed information discussed in the Romanian volume. However, it is a useful tool for the understanding legal information and the appropriate processing of the Romania-Hungarian legal terminology. A thorough acquisition of the general theory of civil law is essential for understanding future civil law topics, and it is the base and framework of the knowledge of civil law. Legal institutions of great practical importance, such as nullity or prescription, are only discussed in detail in the framework of the general theory of civil law, so this is not just an introductory subject of only theoretical significance. The practice demonstrated that using this additional book, the results at the exams conducted in Romanian became higher than in previous years. ${ }^{7}$

This civil law textbook introduced a new method of teaching Romanian-Hungarian legal terminology, developed within the framework of the bilingual, Romanian-Hungarian legal education at the Sapientia University: the students work with Romanian and Hungarian jurisprudential texts simultaneously so that they can acquire the competences of real Romanian and Hungarian legal bilingualism. The core of this method is not substituting Romanian language legal education required by specialized professional examination systems for access to legal professions, but making use of the benefits of teaching in the mother tongue for a more thorough preparation of the students. Another exciting feature of this 2016 book is that it builds upon György Fekete's 1958 volume (not in the continuity of teaching methods but in terminology). Since the start of this experiment, the entire private law taught in Romanian is now covered by Hungarian language textbooks as well, the

\footnotetext{
7 Hungarian is a non-Indo-European language with a specific grammar, which adds to the difficulty of learning legal texts in any Indo-European dialect. The new teaching method (introduction of a Hungarian textbook) increased the performance of excellent students by $7 \%$ and of average students by $4 \%$ compared to the 2015/16 university year at the exam conducted solely in Romanian.
} 
task was completed in 2020 with the publication of the last textbook on the Romanian law of successions in Hungarian. A similar evolution is ongoing regarding criminal law and procedural laws.

Offering legal education at least partially in Hungarian is essential to the Hungarian minority in Transylvania. It is a reasonable goal that the Hungarian language can become at a particular moment of national reconciliation, an official regional language in Transylvania. However, this requires not only political conditions but also a living Hungarian legal language. In Switzerland, for instance, the unitary private law is applied in German, French, and Italian as well. One stimulating experience is that of New Brunswick, Canada. According to Fernand de Varennes: "Education is the foundation stone for the development and the realization of the potential of linguistic minorities... This has been the experience in New Brunswick, Canada, where the first school to teach law in the language of the French minority opened less than 40 years ago at the Université de Moncton. Of course, the situation there is entirely different from Romania and other countries in Europe: French became an official language in New Brunswick some 40 years ago, and it must be used as a language in court by the judiciary equally to English. The lessons and impact of legal education in the minority's language have been astounding. In addition to an increasing number of lawyers and judges who come from the French-speaking minority in New Brunswick-about 30\% of the population, some 250,000 people in the whole province-members of the minority through legal education in their language have come to become members of the political, economic, social and even cultural elite of the province. This has in no small amount permitted the linguistic minority to improve its financial and social standing-dramatically in the last four decades" [8: 41-42]. ${ }^{8}$ Also, professor Fernand de Varennes stated: "In the context of an increasingly globalized world, legal education in more than one language is additionally widely practiced in many countries, and can be beneficial to protect the rights of minorities and contribute to their vitality — and their opportunities" [8: 31].

The normality of legal education in Transylvania should mean that Romanian and Hungarian language legal education can coexist, and can even cooperate effectively and closely.

Legal education in Cluj/Kolozsvár/Klausenburg in the modern era

\begin{tabular}{|c|c|c|c|}
\hline Period & University & Sovereignty & Language of education \\
\hline $1872-1919$ & Franz Joseph University & $\begin{array}{l}\text { Austro-Hungarian } \\
\text { Empire }\end{array}$ & Hungarian \\
\hline 1919-1940 & Ferdinand I University & Romania & Romanian \\
\hline $1940-1945$ & Franz Joseph University & Hungary & Hungarian \\
\hline \multirow[t]{2}{*}{ 1945-1959 } & Victor Babeș University & Romania & Romanian \\
\hline & Bolyai University & Romania & Hungarian \\
\hline 1959-present & Babeș-Bolyai University & Romania & Romanian \\
\hline
\end{tabular}

\footnotetext{
${ }^{8}$ For more details on New Brunswick, see also [9: 153-162]. For the Basque situation see [10: 67-92]; for Wales [11: 49-66]; for South Tirol [12: 93-114] etc.
} 


\begin{tabular}{|c|c|c|c|}
\hline Period & University & Sovereignty & Language of education \\
\hline 2010-present & Sapientia University & Romania & $\begin{array}{l}\text { Bilingual education } \\
\text { (Romanian and Hun- } \\
\text { garian) }\end{array}$ \\
\hline
\end{tabular}

\section{Language of Judicial Proceedings}

Transylvania, in the broad sense we use today includes all the territory gained by Romania from Hungary in 1920, and this includes the real, "historical" territory of Transylvania, and part of Maramureş, the Partium, and the Banat. However, thanks to the successful politics conducted by Romania, at the end of WWI, he acquired territories not only from Hungary but also from other states: part of Bukovina from Austria, Bessarabia from Russia, Southern Dobrogea from Bulgaria. The legal system of "Greater Romania" thus created showed, in consequence, a very fragmented picture.

In substantive civil law, six legal systems coexisted. In the "Ancient Kingdom" (formed in 1859 by the unification of the principalities of Wallachia and Moldavia, which has been called Romania since 1866), the French-inspired "Codul civil" was adopted in 1864. In the historical Transylvania was in force the Austrian Civil Code. In the other areas annexed from Hungary to Romania, the old rules of Hungarian customary private law dating from before December 1, 1918. A specific set of rules, adopted after the Austro-Hungarian Compromise of 1867, such as the Commercial Act XXXVII from 1875 was in force in the whole territory acquired from Hungary. In Southern Dobrogea and Quadrilater (territories acquired from Bulgaria), the law of the pre-WWI Romanian Kingdom was generally applied, excepted the case of the Muslims living there, which applied their own rules regarding family or inheritance. In Bessarabia, besides Russian law, the Hexabiblos (1345) still was in force, and from 1921, except a few details, the Romanian law was extended to that territory.

Nor was the situation much simpler in the area of procedural laws. There were four parallel codes of civil procedure: the Romanian Code of Civil Procedure (1864), modeled on French rules, and the legislation of the Swiss canton Geneva. In Transylvania, Act I of 1911, the Hungarian Code of Civil Procedure was applied. In Bukovina, the Austrian, in Bessarabia, the similar Russian pieces of legislation were applicable.

The first method has the advantage of being fast, but it would have completely ignored the local characteristics and, very interestingly, had not received the support of Romanian lawyers in the newly acquired areas. The advantage of the second method was that it allowed the local features to be taken into consideration, at least in part, and it would have achieved not only standardization but also legal reform and modernization for the whole of Romania.

In the interwar period, one method or the other was on the agenda. The benefits of adopting reform codes have been acknowledged. The first method of completing the process of unification by rapid elimination of the protracted and exaggerated legal particularities in contradiction with the unitary character of the 
Romanian nation-state was raised several times. The extension of the pre-WWI Romanian Kingdom's law to Transylvania came primarily under the mandate of Constantin Hamangiu, Minister of Justice (1931-1932), and Hamangiu coordinated serious preparations for it. However, the death of the minister and the fall of the government prevented these plans from being realized.

Romania adopted a new constitution in 1923. This piece of legislation defined the Romanian Kingdom as a single and indivisible national state and stated that the official language is Romanian.

Practically, after the change of sovereignty in 1918/1920, the Hungarian Act XLIV of 1868 on the equality of nationalities remained in force at least temporarily. This law granted the right to conduct judicial proceedings in minority languages $(7-13 . \S \S)$ if that minority represented one-fifth of the population in a respective territorial-administrative unit. In 1919 a law-decree acknowledged the effects of this previous Hungarian law. Practically, the earlier rights of the Romanian minority in Hungary were recognized as rights of the Hungarian minority in Romania. However, in reality, the use of Hungarian language in judicial proceedings abruptly disappeared.

As it was stated earlier, in the territories annexed from Hungary to Romania, Act I of 1911, the Hungarian Code of Civil Procedure was applicable. Sándor Plósz, who taught at the Franz Joseph University in Cluj/Kolozsvár between 1872 and 1881, drafted the Code, and it was an effective piece of legislation well recognized also by Romanian lawyers in Transylvania.

The code was referred to and applied as the Transylvanian Code of Civil Procedure ("Codul de procedură civilă din Transilvania"). The Romanian translation of the Hungarian laws passed before 1918 had its legal foundation in the Hungarian Act XLIV of 1868 on the equality of nationalities. This law provided: "The laws shall be in Hungarian but shall be published in the language of any other nationality living in the country in an official translation." According to the current state of research, the translation of the Hungarian Code of Civil Procedure was not yet available at the time of the change of empire. The first translation identified by me was published in Romanian in 1920 (translated by Ulvineanu, Ianculovici, and Ghițeanu), followed by another translation (Moisil) in 1924. In 1925 a new Romanian translation was published (by Papp and Balașiu, judges of the Cluj/Kolozsvár Court of Appeals), which also synthesized and described the Hungarian judicial practice before 1918 [13]. This last volume, compiled by two judges who held this function when this territory was part of Hungary, justifies the publication of the official explanatory notes. They wrote that for judges who have moved to recently to Transylvania (from the pre-WWI Romania), before studying and applying the Transylvanian legal systems is not sufficient just to read the text of the law but must understand the system, the logic and the aims of the law. This requires an understanding of the official explanatory notes, including the rich material of comparative law included. The introduction of this volume also refers to the fact that the "old Transylvanian civil procedure" (Hungarian Act LIV of 1868 on the Code of Civil Procedure) is still applicable in certain cases. The Romanian translation of this was not considered necessary because the number of such cases was low, and there are Romanian "judges of Transylvanian 
origin in almost every court who, we believe, will not refuse help from their new colleagues ..."

This sentence shows that a fundamental change took place with the Hungarian system of the judiciary in Transylvania. Many judges came from pre-WWI Romania. Hungarian lawyers and administrative personnel who refused to take the oath to King Ferdinand I and Romania lost their function and pension rights after years of service. In Cluj, for example, the entire personnel of the court of appeals refused to take the oath, except the German Gustav Haupt (who was still an active judge in 1934, according to the organizational scheme of the Cluj/Kolozsvár Court of Appeals). The situation was similar in the Tîrgu-Mureș/Marosvásárhely court of appeals and whole Transylvania. The main reason for the rejection to take the oath was, moreover, the fear that this would be interpreted as a declaration of loyalty towards Romania, who occupied Transylvania militarily, and one might use it as an argument against Hungary at the peace talks. Courthouse buildings were mostly taken over by the Romanian army in 1919. The state gave to the few remaining Hungarian judges and prosecutors 12 months to learn Romanian and, similarly, 6 months to attorneys. The new judges were recruited extremely quickly from Romanianspeaking lawyers in Transylvania, such as attorneys (more than 100 Romanian attorneys took up the post as judges at that time), and a significant number of lawyers also came from the pre-WWI Romania [14: 12].

Therefore the Hungarian Act XLIV of 1868 on the equality of nationalities still in force granted in vain linguistic rights to minorities in the judiciary if the personal conditions for the exercise of these rights rapidly eroded. According to a declaration from the Romanian National Assembly of December 1, 1918, which forms the basis of the "union" between Transylvania and Romania, the latter grants to the cohabiting national minorities full national freedom, including the right to litigate in their language and to resolve disputes by individuals of their community. The undertaking contained in this declaration, although scholars do not dispute the legal nature and content of the document, has not been implemented. This is the case of the Minority Treaty of $1919^{9}$ as well, which in article 8 also granted in general terms the right to use non-Romanian speech, either orally or in writing, before the courts [15: 42-43].

Romania has tried to achieve legal unity through new codes. In 1938 a new Commercial Code was adopted (amended in 1940) and in 1939 a new Civil Code (also amended in 1940) and a new Code of Civil Procedure, which in turn were formally replaced by a new Code (actually a newer version of the original text) in 1940. All three codes were modern pieces of legislation, reflecting a serious professional effort, but offering a solution with controversial content to several issues. Their preparation was based on extensive professional collaboration. The Legislative Council, judges, attorneys, university professors, and parliament members worked together to write and finalize the text. The title of the codes also included the name of King Carol (Charles) II, indicating that in Romania, the king had introduced a one-person corporatist dictatorship from 1938 onwards. The intended date of entry into force of

\footnotetext{
9 Treaty between the Principal Allied and Associated Powers and Roumania, signed at Paris on December 9, 1919, and went into effect on July 16, 1920.
} 
those codes would have been September 15, 1940. However, in June 1940, Romania lost Bessarabia and Northern Bukovina as a result of an ultimatum issued by the Soviet Union, and at the end of August, the Second Vienna Award returned Northern Transylvania to Hungary.

As a consequence of territorial losses in early September, King Charles II. was overthrown, left the country, and the power was concentrated in the hands of the dictator Ion Antonescu. The new political rulers postponed the entry into force of the codes indefinitely. Interestingly, in the printed 1940 Code of Civil Procedure, the king's name was blanketed everywhere, on the cover and inside the volume, and the volume was sold in this way. The reason for this contemporary damnatio memoriae is that the Iron Guard ${ }^{10}$ who came to power alongside Ion Antonescu held him responsible for the 1938 execution of their founding leader, Corneliu Zelea Codreanu. The Iron Guard did not like the fact that Charles II. had been in a relationship for almost two decades with Elena Lupescu, of Jewish descent (they later married in emigration). The Romanian legislature introduced pre-WWI Romanian law in southern Transylvania as early as 1943 (Law 389/1943) and in Northern Transylvania, which returned to Romania in 1945, immediately after the Soviets handed over the territory to the Romanian administration (Law 260/1945). The Romanian Code of Civil Procedure of 1864, previously considered inappropriate, replaced the Transylvanian one, and the same happened with the material legislation as well. This completed the legal integration of Transylvania into Romania. The Code of Civil Procedure of 1940 never came into force.

Regarding the use of Hungarian language in courts in Transylvania, a change occurred after WWII. In the very same historical context as the Bolyai University was founded, the legislator passed a minority-friendly Romanian Law 86/1945 on the Statute of Nationalities. János Demeter, one of the professors of the Bolyai University, drafted the text.

Essential provisions, such as paragraph 8 of this Law states:

Tribunals and courts having jurisdiction over judicial districts in which, according to the latest census, at least $30 \%$ of the inhabitants are speaking a language other than Romanian, shall:

(a) accept any document written and submitted by residents of that constituency that belong to the community that forms the $30 \%$ without requiring their translation into Romanian;

(b) rule on the documents in the same language;

(c) listen to the parties in their mother tongues.

Therefore in 1945, the Hungarian language returned to the courts beside Romanian. According to paragraphs 9 and 12 from the Statute of Nationalities, the judges needed to know the language of the respective ethnic groups as well. The regulation accepted that the official language of the Romanian state is Romanian, yet,

\footnotetext{
10 (Garda de Fier) was the central organization of the Romanian fascist and extreme nationalist movement, rooted in Eastern Orthodox Christianity. The Iron Guard also functioned under the name Legion of the Archangel Michael.
} 
according to the concept realized by the Statute of Nationalities, there was no conflict or tension between the official nature of the Romanian language and the use of Hungarian in judicial context.

However, from the 1970s, in Romania, trials have not taken place in Hungarian anymore, regardless of the ratio of nationalities. The Statute of Nationalities was never formally repealed (theoretically is still in force), but its application gradually ceased, and the process began precisely with the abolition of the Hungarianlanguage legal education at the Bolyai University (1959). This situation has not changed since then: judicial proceedings take place only in Romanian, no matter the percentage of national minorities in the district of a particular court.

\section{Contradictions and Parallels}

From the two historical analyses given above, certain contradictions and parallels are evident.

The contradiction arises between the text of the law and realities: the laws created the framework for the use of minority languages in courts, but this was effective only for a very short period (mainly two decades from 1945). The Hungarian minority regulation of 1867 still in force between the two world wars or the Minority Statute of 1945 to this day ensured the use of mother tongue in the courts, but for the longest part of the period under study, the text of the law and reality contradicted each other.

The use of Hungarian in courts in Transylvania was possible when legal education in Hungarian existed as well: obvious parallelism. The period of the use of Hungarian as judicial language is longer than that of the Bolyai University. The explanation for this is that the effects of the Hungarian legal education disappeared only gradually after abolishing the legal education in Hungarian in 1959. Therefore Hungarian or practically a bilingual (Romanian-Hungarian) legal education is necessary to make the law effective again-besides political will, which is also a complicated element.

Moreover, if we look at the status of different minority rights in Romania in the twentieth century compared to the present, it is possible to build an entire political program on the re-recognition of those rights, institutions, and solutions that were recognized by the Romanian State at a given point, and later were diverted, dismantled, terminated overtly or covertly. Legal education in Hungarian was possible in the context of the Bolyai University (a public university), between 1945 and 1959, and now it is possible only in the context of a private university, founded by historical churches and financed mainly by the Hungarian government and without any regular Romanian public funding. Also, the use of Hungarian in courts was once legally and practically possible, which is not the reality of the present. Now the effective use of a minority language in courts is perceived as an infringement to the status of Romanian as the official language of the state. 
A considerable effort is made to reestablish, develop, and refine the Hungarian legal terminology of Romanian law (the legal terminology in use in Hungary is in its main lines, but not in every detail fit this purpose). ${ }^{11}$ Several textbooks were published, and the bilingual education provided by Sapientia University seems successful. The explanation is simple: proficient, adequate legal knowledge acquired in the mother tongue (i.e., in Hungarian) can be used to build Romanian language tools and professional skills more swiftly. Many states' actual practice recognizes such linguistic rights, as was the case in the past in Romania. Hungarians in Romania are confident that their language can once again play a role also in the judiciary, and there is a need for legal bilingualism of Hungarian lawyers. Knowledge of the Romanian language is necessary, but the Hungarian legal language must be part of the legal culture of ethnic Hungarian lawyers in Romania.

Acknowledgements Open access funding provided by Sapientia Hungarian University of Transylvania.

Open Access This article is licensed under a Creative Commons Attribution 4.0 International License, which permits use, sharing, adaptation, distribution and reproduction in any medium or format, as long as you give appropriate credit to the original author(s) and the source, provide a link to the Creative Commons licence, and indicate if changes were made. The images or other third party material in this article are included in the article's Creative Commons licence, unless indicated otherwise in a credit line to the material. If material is not included in the article's Creative Commons licence and your intended use is not permitted by statutory regulation or exceeds the permitted use, you will need to obtain permission directly from the copyright holder. To view a copy of this licence, visit http://creativecommons.org/licen ses/by/4.0/.

\section{References}

1. Gyula, Juhász. 1987. The Second Vienna Award. Danubian Historical Studies 1: 23-38.

2. Sándor, Vita. 2015. Erdélyi gazdaság, erdélyi politika Tanulmányok, cikkek, dokumentumok, 1933-1946. Kolozsvár: Polis.

3. Emőd, Veress, and Kokoly Zsolt. 2016. Jogászképzés a Bolyai Tudományegyetemen 1945-1959. Kolozsvár: Forum Iuris.

4. György, Fekete. 1958. Polgári jog. Általános rész, személyek és dologi jogok. Kolozsvár: Bolyai Egyetem.

5. László, Szabdédi. 2014. Két világ közt harmadiknak. Vers, próza, dráma, tanulmány, dokumentum. Kolozsvár: Komp-Press.

6. Ernest Lupan, Pantilimon Rikhárd-Árpád, Sztranyiczki Szilárd and Veress Emőd. 2012. Drept civil. Partea generală conform noului Cod civil. București: C.H. Beck.

7. Emőd, Veress. 2016. Román polgári jog. Általános rész. Kolozsvár: Forum Iuris.

8. de Varennes, Fernand. 2016. Teaching law in Minority Languages: Benefits and Impacts for Individuals and Communities. In Multilingualism and Law, ed. Veress Emőd, 29-41. Kolozsvár: Forum Iuris.

9. McLaren, Karine. 2016. The Implications of Legal Bilingualism on the Teaching and Practice of Law in Canada. In Multilingualism and Law, ed. Veress Emőd, 153-162. Kolozsvár: Forum Iuris.

10. Arzoz, Xabier. 2016. Making a Minority Language a Higher Education Language: The Teaching of Law Trough the Basque Language. In Multilingualism and Law, ed. Veress Emőd, 67-92. Kolozsvár: Forum Iuris.

11. Parry, Gwynedd R. 2016. The Council of Legal Education in Wales: An Idea Whose Time has Come? In Multilingualism and Law, ed. Veress Emőd, 49-66. Kolozsvár: Forum Iuris.

12. Alber, Elisabeth. 2016. Multilingualism, Legal Education and Cross-border Cooperation: Evidence from South Tyrol. In Multilingualism and Law, ed. Veress Emőd, 93-114. Kolozsvár: Forum Iuris.

\footnotetext{
11 Details and examples are discussed in [16]. The Sapientia University started to construct an online database of juridical language as part of a standardization process of Romanian civil and criminal law's Hungarian legal terminology. The general public will have access to the first finalized parts of this database this year.
} 
13. Papp, Ioan, and Paul Balaşiu. 1925. Codul de procedură civilă din Transilvania. Cluj: Editura Curţii de Apel Cluj.

14. Papp, Ioan P. 1945. Instaurarea justiției românești în Ardeal. Transilvania 76 (1): 1-31.

15. Parry, Gwynedd. R. 1921. Peace Treaties. Various Treaties and Agreements between the Allied and Associated Powers and the Serb-Croat/Slovene State, Roumania, Bulgaria, Hungary, and Turkey. Washington: Government Printing Office.

16. Emőd, Veress. 2020. Román polgári jog. Általános rész. 4. kiadás. Kolozsvár: Forum Iuris.

Publisher's Note Springer Nature remains neutral with regard to jurisdictional claims in published maps and institutional affiliations. 